\title{
Breaking the silence: Palaeontology and evolution in La Vanguardia Española (1939-1975)
}

\author{
Clara Florensa (*) \\ ${ }^{*}$ ) Centre d'Estudis d'Història de la Ciència, CEHIC. Universitat Autònoma de Barcelona. \\ Clara.Florensa@uab.cat
}

Dynamis

[0211-9536] 2013; 33 (2): 297-320

\author{
Fecha de recepción: 5 de agosto de 2012 \\ Fecha de aceptación: 28 de febrero de 2013
}

SUMARIO: 1.-Introduction. 2.-Appropriation background: 19th and 20th century. 3.-La Vanguardia Española and press policy in the Franco regime. 4.- The evolutionist silence. 5.-Breaking the silence: Spanish palaeontologist evolutionism. 6.-Palaeontology as part of the regime's propaganda effort. 7.- «Evolutionary rules» and appropriation transferences. 8.-Crusafont and the popularity of palaeontology. 9.-From the monkey grandfather to the hydrogen great-great-grandfather. 10.-Conclusions.

\begin{abstract}
All traces of evolutionary theories had been removed from the Spanish public sphere during the late stages of the Civil War and early Francoism. Darwin's books were cleared from the shelves of libraries and bookshops and evolutionism was replaced by creationism in primary and higher education manuals. In the public sphere, there was a mixture of concepts concerning evolution that were borrowed from different evolutionary theories, some of them outdated. Talking about evolution in the press meant talking in a nineteenthcentury manner about the ape origin of man, materialism and threat to the Catholic faith. In other words, evolution was something unpleasant and dangerous. In this context, certain Spanish palaeontologists went to considerable lengths to try and avoid all of this bad popular imaginary (linking it to Darwinism), and to rehabilitate evolutionism from a finalistic-theistic point of view, which fitted in well with the ideology of the Franco regime. This effort, which succeeded in bringing evolutionism back into the public sphere following a period of «evolutionary silence», was relegated to second place when a new period of regime openness came about. The more scientific jargon of genetics and Modern Synthesis, which was less conducive to origins and theological discussion, fitted in better with the aims of the new regime, thus changing public scientific authority from bones to genes. This paper highlights the ongoing process of the appropriation of evolutionary theory through the case study of the presence and treatment during Francoism of the theory of evolution in the Catalan newspaper La Vanguardia Española.
\end{abstract}

KEY WORDS: Evolutionary theory, Darwinism, Francoism, science and dictatorship, censorship, science and the press, Synthetic theory.

PALABRAS CLAVE: teoría evolucionista, darwinismo, franquismo, ciencia y dictadura, censura, ciencia y prensa, teoría sintética. 


\section{Introduction}

In 1938, Franco's first Education Minister, Pedro Sáinz Rodríguez, referred to the theory of evolution as «having had its time» ${ }^{1}$. At the same time, the basis of the Modern Synthesis of evolution was starting to take root abroad. This rescued Darwinism from its turn-of-the-century decline by providing a possible mechanism for natural selection and replaced the finalist theories that had gained popularity ${ }^{2}$. The evolution debate was heating up and there were a number of new approaches. However, this did not happen in Spain, where evolutionary theory was tainted with a Republican and anti-clerical stigma that the regime was eager to eradicate. In the public sphere, rejection of evolution did not only target Darwinism, but all kinds of evolutionary theories, as they all were seen as dangerous to the Catholic faith ${ }^{3}$. In fact, any mention of them was removed from catechisms and education manuals and Darwin's books were cleared from the shelves of Spanish libraries and bookshops ${ }^{4}$.

This paper analyses how evolutionary theory was dealt with in the widely read Catalan newspaper La Vanguardia Española during Franco's regime (1939-1975), revealing a case of evolutionary silence that lasted for more than ten years. This case study also shows an ongoing appropriation of evolutionary theory and highlights how it shifted over the course of nearly four decades of dictatorship, following the changes in the regime. The theory of evolution during that time was broadly understood at $\mathrm{La}$ Vanguardia Española and referred to in a general way as a mixture of ima-

1. «Una estrella apagada». From a speech given by Pedro Sáinz Rodríguez at the University of Santiago in June 1938. Alted, Alicia. Política del nuevo estado sobre el patrimonio cultural y la educación durante la Guerra Civil española. Madrid: Dir. Gral. de Bellas Artes y Archivos del Centro Nacional de Información Artística, Arqueológica y Etnológica; 1984, p. 215. All translations from Spanish sources are mine.

2. Bowler, Peter J. The eclipse of Darwinism. Anti-Darwinian evolution theories in the decades around 1900. London: Johns Hopkins University Press; 1983, p. 5.

3. Blázquez, Francisco. El evolucionismo en España y la síntesis neodarwinista (1939-1970). Madrid: Universidad Autónoma de Madrid; 2004, p. 211-212.

4. Blázquez, n. 3, p. 212. The book that best illustrates the lack of Darwin's works on the theory of evolution in Spain from the end of the Civil War until the 1960s is Gomis, Alberto; Josa, Jaume. Bibliografía crítica ilustrada de las obras de Darwin en España (1857-2008). 2nd. ed. Madrid: CSIC; 2008. There is an exception to this absence: in 1950 circulation and sale of one 1936 edition of El origen de las especies (ed. Bergua) was authorised. See Gomis; Josa, n. 4, p. 144. 
ges and ideas, some of them retrieved from the 19th century and widely abandoned abroad long before.

This paper will highlight the key role played by palaeontology in breaking the «evolutionary silence». By supporting a finalistic-theistic view of evolution, a group of Spanish palaeontologists opened the doors to evolution into the public arena. The press coverage also indicates the importance given to local scientists in the Francoist press, especially to Miquel Crusafont (1910-1983), a Spanish palaeontologist ${ }^{5}$ who was depicted practically as a national hero in the pages of La Vanguardia Española. The Franco regime used science in the press as a form of propaganda to build a public image of a wealthy, strong and capable Spain ${ }^{6}$. This reconstruction will highlight how Spanish scientists were used to stimulate national pride and confidence for that propagandistic purpose.

Moreover, this case study will highlight how the appropriation of scientific knowledge can influence the appropriation of its related disciplines. Even though palaeontology helped get the theory of evolution back into the newspaper after the Civil War, it also «suffered» from evolution's «bad reputation». As the evidence to prove the theory could emerge from this discipline, palaeontology was seen as a dangerous source of knowledge to be handled with care. On the other hand, when Modern Synthesis emerged in the pages of La Vanguardia Española it was characterised by genetics and biochemistry with a more «scientific» language, rather than that of human origins, which was more akin to a philosophical and religious debate.

Evolution during the Francoist period has been disregarded in historical studies, but it raises interesting questions. The few existing studies have taken a valuable in-depth look at education and academia ${ }^{7}$, but have not looked very closely at the public sphere. By analysing La Vanguardia Española, I attempt to contribute to a better understanding of the treatment and appropriation of the theory of evolution in the public domain in this particular period. Alvar Ellegård said in his Darwin and the general reader $^{8}$ (1958) that «the press can be taken to reflect, more accurately

\footnotetext{
5. Acosta, Carlos; Catalá, Jesús Ignacio, in this dossier.

6. Santesmases, María Jesús. Severo Ochoa and the biomedical sciences in Spain under Franco, 1959-1975. Isis. 2000; 91 (4): 706-734 (734).

7. Blázquez, n. 3. Iglesias, Alfredo. Una investigación en España sobre o evolucionismo humano (1936-1976). Santiago de Compostela: Universidad de Santiago de Compostela; 1998.

8. Ellegård, Alvar. Darwin and the general reader. The reception of Darwin's theory of evolution in the British periodical press, 1859-1872. Göteborg: Göteborgs Universitets Arsskr; 1958. This
} 
than any other source material, the climate of opinion» ${ }^{9}$. Many have since claimed the importance of studying the boundary between expert, esoteric knowledge and the exoteric knowledge found in, for instance, the popular media. It has even been claimed that «in any historical study of science, that boundary ought to be a critical site for investigation» ${ }^{10}$. In a situation of strict control and censorship of information such as during the Franco dictatorship, it may be more difficult to infer the climate of opinion from the newspapers. Nevertheless, the intrinsic tension seen in the press, as businesses involved in providing information, shows an interesting compromise between what the public wanted and what was allowed by the censors. This special context adds even more interest, if that were possible, to one of the questions James Secord raises in his «Knowledge in Transit»: «How and why does knowledge circulate?» ${ }^{11}$.

\section{Appropriation background: 19th and 20th centuries}

In approaching this case, it is indispensable to take into account the appropriation processes that involved evolution when it first arrived in Spain, as some of them shaped those that took place during the Franco regime. The reception of Darwinism in 19th century Spain is a well-studied case $^{12}$. Historians have shown that it was not simply pure dissemination of scientific knowledge, but an appropriation in which the context of Spain

book constitutes a detailed study of the changes in British public opinion which took place following the 1859 publication of The Origin of Species, based on an analysis of the periodical press of the period.

9. Ellegård, n. 8, p. 5.

10. Secord, James A. Knowledge in transit. Isis. 2004; 95 (4): 654-672 (671).

11. Secord, n. 10, p. 655.

12. For example: Glick, Thomas; López-Piñero, José María. Darwin en España. Barcelona: Península; 1982. Glick, Thomas; Puig-Samper, Miguel Ángel; Ruiz, Rosaura, eds. The reception of Darwinism in the Iberian world: Spain, Spanish America and Brazil. Dordrecht: Kluwer Academic; 2001. Núñez, Diego. El Darwinismo en España. Madrid: Castalia; 1977. Pelayo, Francisco. Darwinism and palaeontology. Reception and diffusion of the theory of evolution in Spain. In: Engels, Eve-Marie; Glick, Thomas, eds. The reception of Charles Darwin in Europe. London: Continuum; 2008, p. 386-399. Camós, Agustí. Darwin in Catalunya: from Catholic intransigence to the marketing of Darwin's image. In: Engels, Eve-Marie; Glick, Thomas, eds. The reception of Charles Darwin in Europe. London: Continuum; 2008, p. 400-412. For a complete critical historiography see Catalá, J. I. Cuatro décadas de historiografía del evolucionismo en España. Asclepio. 2009; 61 (2): 9-66. 
at that time, a moment of revolution, played a central role ${ }^{13}$. Some sectors of society adopted evolutionary theory and used it as both a symbol for their own ideals and as an instrument to back a host of often very different arguments. It was associated with progressivism, liberal thinking, revolution, socialism, communism, etc. and was also regarded as an anti-clerical idea, not only because it clashed with certain parts of Catholic dogma, but also because most of the aforementioned movements were also associated with atheism and anticlerical ideas. Conservatives therefore disapproved of it ${ }^{14}$.

In the 20th century, before and during the Civil War, many supporters of evolutionary theory joined the Republicans ${ }^{15}$. After winning the war against the Spanish Second Republic, Franco used censorship and depurative policies to wipe out any trace of Republicanism that, by association, also affected the theory of evolution ${ }^{16}$. In addition, from 1945, Franco strengthened his ties with the Catholic Church in order to avert political pressure from Europe. Following the fall of his fascist allies at the end of World War II, he needed the Church's support to change the image of his policies by enhancing the Catholic elements and hiding those of a fascist nature, especially to the outside world. Catholic collaborationists offered him the powerful Catholic press network to defend the regime's cause abroad, but in return they demanded a more Catholic policy from the regime $^{17}$. In practice this meant that political posts such as those in charge of censorship and education fell into Catholic hands ${ }^{18}$. Thus, control of the information reaching the public domain had to strictly follow Catholic

13. In Spain, when the theory of evolution arrived there was a progressive and liberal revolution called La Gloriosa, which started in September 1868 and led to the First Spanish Republic. Glick and López-Piñero, n. 12, p. 13-49. See also: Glick, T. Science and the Revolution of 1868. Notes on the reception of Darwinism in Spain. In: Lida, Clara E.; Zavala, Iris M., eds. La Revolución de 1868. Historia, pensamiento, literatura. Nueva York: Las Américas; 1970, p. 267-272.

14. Glick; López-Piñero, n. 12, p. 13-64.

15. Blázquez, F. La recepción del darwinismo en la universidad española (1939-1999). Anuario de historia de la Iglesia. 2009; 18: 55-68 (56) and Blázquez, n. 3, p. 255.

16. Blázquez, n. 15, p. 56-58 and Blázquez, n. 3, p. 254-257. In Spain, Republican periods generally coincide with periods of progressivism.

17. Preston, Paul. Franco. Caudillo de España. Barcelona: Grijalbo; 1994, p. 665-666 and Tusell, Javier. Franco y los católicos. La política interior española entre 1945 y 1957. Madrid: Alianza Universidad; 1990, p. 35.

18. For detailed names see Bermejo, Benito. La Vicesecretaría de educación popular (1941-1945). Un «ministerio» de la propaganda en manos de Falange. Espacio, tiempo y forma. 1991; 4: 73-96, p. 89. 
dogma, which, although not officially, implicitly condemned evolution as a heresy ${ }^{19}$. Evolutionism would later be expressly linked to communism by Pope Pius XII in the Humani generis encyclical ${ }^{20}$. Thus, in the climate of the Franco dictatorship, evolution would be at least a double heresy ${ }^{21}$.

\section{La Vanguardia Española and press policy in the Franco regime}

How far does this case reflect what could be found regarding evolution in the public domain? In this section, I will defend that this newspaper can be taken as a good survey case model for such a study ${ }^{22}$. It must be borne in mind that the dictatorship controlled all the media, particularly the press, by reading all pre-prints before they reached the public. Thus, a certain uniformity was characteristic of the press, especially in early Francoism. Moreover, after the Civil War there was a radical reduction in the amount of press available and, among the four sole surviving newspapers on the streets of Barcelona (seven from 1940 to 1964), reduced from the previous 26, La Vanguardia Española was the most widely read ${ }^{23}$.

La Vanguardia is one of the oldest newspapers in Spain. It was founded in 1881 and has been published without interruption ever since, except during the Civil War. This demonstrates a considerable ability to adapt to political and social changes. At the end of the Civil War, the day after

19. See Providentissimus Deus encyclical and canon 1399, which also promoted control of printed material. For further information see Collado, Santiago. Breve recorrido histórico sobre la posición del Magisterio de la Iglesia frente al evolucionismo. Temas de actualidad familiar. 2010: 95-111.

20. Pius XII, Encyclical Humani Generis, 22 Aug 1950 [cited: 15 Jul 2012]. Available from: http:// www.vatican.va/holy_father/pius_xii/encyclicals/documents/hf_p.xii_enc_12081950_humanigeneris_en.html.

21. Blázquez, n. 15, p. 56 and Blázquez, F. A Dios por la ciencia. Teología natural en el franquismo. Asclepio. 2011; 63: 453-476 (455).

22. Furthermore, the hypotheses made here are supported by the results found in parallel research on the $A B C$ newspaper, another influential and widely read newspaper during the Franco period, and ongoing research in the Biblioteca Virtual de Prensa Histórica. [cited: 8 Jul 2012]. Available from: http://prensahistorica.mcu.es/es/estaticos/contenido.cmd?pagina=estaticos/ presentacion.

23. Huertas, Josep Maria. Una Història de «La Vanguardia». Barcelona: Angle Editorial; 2006. p. 121 and Huertas, J.M. Periodistes. Base de dades. Catalunya durant el franquisme. [cited: 1 Jul 2012]. Available from: http://www.cefid.uab.cat/. 
the occupation of Barcelona by Franco's troops in 1939²4, La Vanguardia appeared with the tagline «Newspaper in the Service of Spain and of Generalissimo Franco» and changed its name from La Vanguardia to La Vanguardia Española. This was a clear statement of intent: the journal was going to follow the new regime and support Franco's Nationalist policies ${ }^{25}$. A first period of recalcitrant censorship came in La Vanguardia Española, later described as a period of «unconditional servitude» ${ }^{26}$, with a director chosen by Franco himself and under a rigid Press and Propaganda Service policy that legally obliged the newspapers to have their drafts pass by the official censors. In 1966, with a new press act and a new director, a period of openness began at the newspaper and a change in vocabulary, style, structure and subject matter can be detected. At first the vocabulary was grandiloquent, praising Spain and Franco, with a very rigid pattern and a paucity of subjects. In the second period, the style relaxed and the subjects diversified. Even though the new Press Act replaced «government censorship» with «voluntary censorship», it still provided for a high level of intervention in communicational policies ${ }^{27}$. It was with good reason that the press was defined in the act as an instrument for channelling public opinion ${ }^{28}$. These policy changes can be traced through an analysis of the presence and handling of evolutionary theory in the pages of the newspaper.

\section{The evolutionist silence}

The end of the Civil War in 1939 was followed by more than ten years of silence regarding evolution in the newspaper. It was not until the $1950 \mathrm{~s}$ that articles mentioning the theory (in the broad sense stated above) reappeared in La Vanguardia Española. Jaume Truyols (b. 1921), a Catalan palaeontologist, points out that talking about evolution in those days was

\footnotetext{
24. Huertas, n. 23, p. 120.

25. Huertas, n. 23, p. 120.

26. Huertas, n. 23, p. 129.

27. For a number of examples of the coercive attitudes and strategies that were put in practice, some as late as the 1970s, see Ruiz, Manuel. Censura y consignas en la prensa franquista. Algunos ejemplos de dirigismo informativo. Ámbitos: revista andaluza de comunicación. 2002; 9-10 (2): 507-529.

28. In the preamble to the new Press and Printing Act: Ley 14/1966, de 18 de marzo, de Prensa e Imprenta. BOE, 67: 19 Mar 1966, p. 3310.
} 
risky, unless you were debunking the theory ${ }^{29}$. The concept of evolution was an idea non grata. It was considered heresy and was replaced by creationism that interpreted the words of Genesis literally ${ }^{30}$. The Minister of Education in Franco's second government and the first president of the CSIC ${ }^{31}$, José Ibáñez Martín, proclaimed in 1940 a Catholic science free of «scientific heresies» ${ }^{32}$ and education manuals replaced the "appearance of man» with the «creation of man» ${ }^{33}$. Special emphasis was placed on surveillance of the popularisation of the theory and La Vanguardia Española blindly supported the rigid control of information according to Catholic dogma imposed by the regime.

There is an exception to this silence. During these more than ten years with no mention of evolution in the newspaper, one article addressed the matter ${ }^{34}$. It was in 1942 and was a report of a lecture on «The enigma of primitive man» given by Renato Llanas de Nubió, a Catalan historian, at the Ateneo Barcelonés, a cultural centre founded in the 19th century to promote intellectual meetings and debate in Catalan society ${ }^{35}$. The lecture was chaired by the Secretario Provincial de Propaganda (Provincial Secretary of Propaganda ${ }^{36}$. Thus, before reaching the public, this information had been through at least a double filter. Had there been any kind of official version of evolution that the regime wanted to circulate among the population, it would presumably have been this one.

29. Blázquez, F. La teoría sintética de la evolución en España. Primeros encuentros y desencuentros. Llull. 2001; 24: 289-313, p. 291.

30. Blázquez, n. 15, p. 56.

31. Consejo Superior de Investigaciones Científicas, an institution created by the Franco government to direct and coordinate Spanish research, inherited from the Junta para la Ampliación de Estudios (JAE) created in 1907.

32. Memoria del CSIC, 1942: 16. From: Elías, C. Influencia de la historia de España (siglos XIX y XX) en el periodismo especializado en ciencia. Revista latina de comunicación social. 2001; 39. Available from: http://www.ull.es/publicaciones/latina/2001/latina39mar/112elias4.htm. See also Blázquez, n. 3, p. 212.

33. Blázquez, n. 29, p. 291.

34. Disertación de don Renato Llanas de Niubó, en el Ateneo. La Vanguardia Española. 28 Nov 1942: 9 .

35. Ateneu Barcelonès [cited: 11 Set 2012]. Available from: http://www.ateneubcn.org/web/index. html.

36. The Departamento de Propaganda (Propaganda Department) was part of every provincial delegation of the Vicesecretaría de Educación Popular (Vice-Secretariat for Popular Education), which was set up in 1941 to strengthen control over all kinds of cultural activities through a network of provincial delegates. Bermejo, n. 18, p. 1. 
What was this «official» version? The report settled the conflict between two views: on the one hand, what Llanas de Nubió presented as Darwinian evolution, which «argued that Man descended from the ape ${ }^{37}$ and «allowed the reconstruction of Man with bestial features», and on the other, the Catholic view of the origin of man from the «sublime poetry of the Bible» which «tells us that man is the creation of omnipotent God's genius». For the former, he established palaeontologists as the scientific authority in the field, a position they would hold for most of the Franco regime, as will be seen. The only evidence offered came from palaeontology and he stressed that this was inconclusive; for the latter, the authority was the sacred texts presented as certain, undeniable truth. He explained that there «seems to be a contradiction between modern science and the Biblical text» ${ }^{38}$. However, according to the lecturer, this contradiction was not real, that there was in fact a misunderstanding, which he was there to straighten out: «Neanderthals from Gibraltar or Banyoles do not match with the evolving ape, but with the perfect Man, created by God, who degenerated ${ }^{39}$.

This article stated the line the newspaper was going to follow when dealing with evolution after the silence. Evolution was discussed alongside religion and was linked to unpleasant images of degenerated ape-like ancestors with bestial features. Religious discussion focused on the points that seemed to threaten the Catholic faith and stressed the veracity of the sacred writings, linked to good images — «sublime poetry»-, which were pitted against palaeontology in a contest for authority in this field. A kind of love-hate relationship evolved as palaeontology was seen to be the science that could prove the theory of evolution right or wrong ${ }^{40}$.

37. The idea of an ape-origin was a stigma from the late 18th century and not Darwinian. Darwin's theory claimed that we only share a common ancestor with apes. Bowler, P. Evolution: the history of an idea. London: University of California Press; 1989, p. 91-92. Bowler, P. Theories of human evolution: a century of debate, 1844-1944. Baltimore: Johns Hopkins University Press; 1986, p. 16.

38. Disertación, n. 34.

39. Disertación, n. 34. Ape-men with bestial features and the theory of «degeneration» were also relics from the 18th century and not even evolutionist. Bowler, 1989, n. 37, p. 92.

40. Pelayo describes a similar situation in the 19th century. Pelayo, F. La paleontología. Un argumento para rebatir al darwinismo en el intento de armonizar Ciencias Naturales y Religión. Actas II Congreso de la Sociedad Española de Historia de las Ciencias. Zaragoza: SEHCYT; 1984, p. 475-488. 


\section{Breaking the silence: Spanish palaeontologist evolutionism}

Beginning in 1950 evolution began to timidly reappear in the newspaper. It is worth noting that it was in 1950 that Pope Pius XII dictated the encyclical Humani generis, which gave learned men the opportunity to debate evolution. This reappearance of the theory was mainly circumstantial: in book reviews, adverts for workshops or lecture reports. There were mainly two kinds of articles regarding the matter: those related to palaeontology and those that were not. The latter, the minority, were commentaries or opinion pieces written by journalists in which evolution was mentioned in passing and followed the pattern shown by the above-mentioned very first article that fully addressed the topic of evolution. On the other hand, in the former, which were the majority, evolution was mentioned as part of scientific activities, maintaining a finalistic-theistic view of evolution which stressed that it was not at odds with dogma and as such was transformed into a pleasant idea. Taking into account the number of articles of the second kind and the effort shown in them to «rescue» evolutionary theory from its stigmas, we could say that palaeontology reintroduced the theory of evolution into the newspaper. A growing figure, Miquel Crusafont, a Catalan palaeontologist and head of the Palaeontology Section at the Museum of Sabadell, offered a version of evolution that fitted in well with the demands of the regime ${ }^{41}$.

In 1953, an account was published of a lecture entitled «Evolutionary Creationism» given by Miquel Crusafont in which he defended evolutionism and pointed out its compatibility with the Catholic religion, as well as ridding the theory of its emotive and ideological charge in an attempt to make it more desirable. At the same time, he was identifying palaeontology as the discipline on which the study of evolution should rest: «[Crusafont] mentioned that the objective and dispassionate study of fossils leads to a reality of evolutionism that is compatible with the idea of God as Creator» ${ }^{42}$.

Crusafont, alongside other Spanish palaeontologists such us Bermudo Meléndez (1912-1999), professor of palaeontology at Madrid University, belonged to a like-minded circle of palaeontologists which he named the «Mediterranean» school of evolutionism in 1951. It was a distinctly Catholic group of mostly French and Italian scholars whose ideas harmonized science

\footnotetext{
41. See Acosta in this dossier.

42. El Dr. D. Miquel Crusafont en la Sociedad Astronómica. La Vanguardia Española. 1 Nov 1953:18.
} 
and religion in what was called concordism ${ }^{43}$. Crusafont defined this school as «finalist-theistic» according to a tradition of Catholic, teleological and orthogenetic evolution ${ }^{44}$. This «Mediterranean style» understood evolution as a process of progress that had a goal (finalism), which also admitted divine intervention (theism) and allowed an intrinsic life force to evolve, due to a «guiding force» (orthogenesis) ${ }^{45}$.

At the beginning of the 20th century, the theory of evolution by natural selection seemed to enjoy a period of decline when no proof for the mechanisms proposed by Darwin was found ${ }^{46}$. Nevertheless, in the $1930 \mathrm{~s}$ and 40s the Modern Synthesis offered a genetic and mathematical approach to natural selection, which brought Darwinian evolutionary theory back to the forefront. The subject could no longer be ignored. Something had to be done and concordism seemed to fit in well with the Spanish case ${ }^{47}$.

\section{Palaeontology as part of the regime's propaganda effort}

Articles reporting on specialised courses and speeches in La Vanguardia Española suggest that palaeontology became important in the transmission of information for the Spanish government as an acceptable way of dealing with the question of evolution. Palaeontologists were the main scientific authority on the subject in the newspaper and Crusafont's view became the official version, to the extent that it was included as part of the new journalist training scheme set up by the regime.

43. The word «concordism» is often used in contemporary works dealing with origins. Derived from the word «concord», meaning a state of harmony, «concordism» has been used sparingly in English for more than a century.

44. Glick, T. Miquel Crusafont, Teilhard de Chardin and the reception of the Synthetic theory in Spain. In: Engels; Glick, n. 12, p. 553-568 (562).

45. Agustí, Jordi. L'evolucionisme meridional de Miquel Crusafont. Arraona, Revista d'Història. 1994. 14: 29-43.

46. Bowler, n. 2, p. 5.

47. Similar concordist strategies to harmonize Darwinism with Catholic religion in 19th century Spain can be found in Pelayo's works. See: Pelayo, F. Debatiendo sobre Darwin en España: Antidarwinismo, teorías evolucionistas alternativas y síntesis moderna. Asclepio. 2009; 61 (2): 101-128. 
In 1939, when the Spanish Civil War ended, Spanish newspapers underwent a radical change ${ }^{48}$. A new official body was created, the Jefatura Provincial de Prensa (Provincial Press Authority), which decided who could continue working as a journalist and who could not. To practise their profession, journalists had to register with the new Registro Oficial de Periodistas (Official Registry of Journalists) and hold a card which was only granted after a full investigation into the applicant's past. In 1941, the Escuela de Periodistas (School of Journalism) was established under the Delegación Nacional de Prensa (National Press Delegation). From then on all journalists had to undergo this training which ended with the issuing of the above mentioned permit. In his speech at the school's inauguration, Juan Aparicio, the National Delegate for the Press, stated that it would teach a «national», «anti-liberal» and «Christian» journalism. Journalists were required to be «teachers of patriotism» with a mission: «the popular education of all Spanish people» ${ }^{49}$. Specialist and orientational courses for journalists appeared in several Spanish cities. One was held in Sabadell in 1956 and Crusafont took part in it.

Sharing a session with a lecture on National Formation, Crusafont taught the future journalists this «regime-style» evolution. La Vanguardia Española reported on one of these lectures titled «Evolution and dogma» in which «Doctor Crusafont expounded on the evolutionary process proposed by the Creation, showing how this evolutionism, which in the previous century had been used to deny the existence of God, was coming, in the present, to irrefutably prove the permanent and eternal presence of the Creator» ${ }^{50}$.

The fact that Crusafont taught in one of these courses highlights the extent to which his version of evolution was acceptable to the regime. Moreover, this report reveals part of the information journalists received regarding the theory of evolution and thus what they would be able or at least were expected to transmit.

\footnotetext{
48. Gassol Bellet, Olivia. Censura. Base de dades. Catalunya durant el franquisme. [cited: 5 Jul 2012]. Available from: http://www.cefid.uab.cat/.

49. Cifra. Diez y siete alumnos de la Escuela de Periodistas reciben su carnet profesional. La Vanguardia Española. 1 Nov 1941: 5.

50. Éxito del I Cursillo de Orientación Periodística. La Vanguardia Española. 28 Mar 1957: 26. All translation from Spanish are mine.
} 


\section{7. «Evolutionary rules» and appropriation transferences}

When analysing the articles that appeared in La Vanguardia Española after the silence, some persistent trends, which I call «evolutionary rules», emerge. Until the late 1960s, journalists, readers, priests, etc. who wrote about evolution in the newspaper followed this pattern, which shaped how the theory of evolution was dealt with in the pages of the newspaper. It will be shown how the articles about palaeontology, which mainly referred to Crusafont's activity, followed only those rules that favoured an acceptance of the theory and fought against those that did not, trying to promote a safe and pleasant image of evolution in the public sphere.

The first «rule» was to maintain the previous silence as far as possible. Evidence of this can be found in the newspaper's response to the centenaries of two important dates in the history of evolutionary theory. The first was that of Darwin and Wallace's presentation of the theory to the Linnean Society in 1858. The second was the first publication of Darwin's book On the Origin of Species in 1859, which also coincided with the 150th anniversary of his birth. These were important events which were marked worldwide $^{51}$. It has been said that these two adjacent centenaries brought Darwin back to life in Spain, as they constituted a starting point for the re-publication of both his books and those related to his work ${ }^{52}$. However, this does not appear to fit in with the case of La Vanguardia Española, as it did not publish a single article dealing exclusively with these events. All that can be found are some references to them in news items about other events, such as a book review ${ }^{53}$ or the end of a course ${ }^{54}$, interestingly enough organised by Crusafont.

There was a second rule: the religious «bodyguard». The first articles on evolution made explicit reference to the observance of the above mentioned Humani generis encyclical. In 1956, Lluís Pericot (1899-1978), a Catalan prehistorian and professor at the University of Barcelona, commented on

51. Smocovitis, Vassiliki Betty. The 1959 Darwin centennial in America celebration. Osiris. 1999; 14, 274-323 (275-276).

52. Blázquez, F. Darwin y el Darwinismo en España a través de sus centenarios (1909, 1959, 1982). In: Cobos, José M.; Pulgarín, Antonio; Ausejo, Elena, eds. X Congreso de la Sociedad Española de Historia de las Ciencias y de las Técnicas. Encuentro internacional europeo-americano 2008. Badajoz: SEHCYT; 2011, p. 133-140. See also Blázquez, n. 15, p. 64.

53. Cien años de evolución. La Vanguardia Española. 25 Nov 1959: 13.

54. Clausura del IV Cursillo Internacional de Paleontología. La Vanguardia Española. 11 Jul 1958: 30. 
a palaeontological find and the paper stated: «interpreting this data [...] Doctor Pericot devoutly observes the orders of His Holiness in the Humani generis encyclical» ${ }^{55}$. The same concern can be found in a 1957 interview with Lluís Solé Sabarís, a geology professor ${ }^{56}$. The journalist asked: «Do Catholic scientists accept the evolutionist theory?» The professor answered:

«There is nothing in evolutionary theory that is against dogma; in the Humani generis encyclical Pope Pius XII said: "Church authority does not forbid talking about evolutionary theory in research and discussions between versed men"» 57 .

The Humani generis encyclical was used as a kind of permit that allowed evolution to be debated in public.

Moving forward to the 1960s, the Humani generis «permit» was less used. Nevertheless, some kind of Catholic warranty was still required. Most articles that mentioned the theory of evolution also specified the religious affiliation of the scientist, added the opinion of a religious person and quoted from the Bible or talked about the Sacred Truth. Scientific authority was not sufficient.

Another «rule» was to make evolution look undesirable. In this regard, there were mainly three associations that tainted the theory.

A strong rejection of the theory in the pages of La Vanguardia Española was linked to the idea that it threatened Catholic dogma and that it would lead to the loss of values and unhappiness through the loss of faith. The following Catholic propaganda advertisement, which occupied the whole third page of the newspaper, illustrates this trend:

«You have been living this way for some time, turning your back on truth. [...] Since then, your will, your sense of duty, your morality and your dignity have begun to weaken. Since then, you have not been happy, of course. [...] Do you remember that day when you read something about the

\footnotetext{
55. Al margen. La Vanguardia Española. 27 Jun 1956: 16.

56. Lluís Solé Sabarís (1908-1985) was a Catalan geologist and geographer. He had already supported the theory of evolution in his work Introducción a la Geología in 1938 (Barcelona: ed. Apolo). See Blázquez, n. 29, p. 300.

57. Del Arco. Mano a mano. Luis Solé Sabarís. La Vanguardia Española. 1 Aug 1957: 13.
} 
theory of the evolution of species and it brought the divine origin of Man into question?» ${ }^{58}$.

Another visible trend associated with the reappearance of the theory of evolution is the sense that a foolish and dangerous optimism was emerging from believing in it: "This unshakable optimism of today's world is a consequence of the era started [...] by "On the Origin of Species" a century ago» ${ }^{59}$. Optimism, it was thought, that came from the idea that man could improve without effort and a sense that nature led to progress, which in turn led to a loss of traditional values:

«The theory of evolution $[\ldots]$ contributed to the thinking that, due to the laws of nature, the new and the modern were necessarily better than the old and that a law of progress dictated that today would be better than yesterday and tomorrow better than today. It was far too optimistic a view» ${ }^{60}$.

This link between the theory of evolution and progress was a heritage of the previous century, even though Darwin's theory itself did not subscribe to the idea of progress. By that time it had been abandoned by most of the new generation of Darwinists abroad, who were aware of the difficulty of making this connection ${ }^{61}$.

Nevertheless, the most persistent and widespread link tied to evolution, and the one people seemed most reluctant to accept, was the idea that the theory dethroned Man as the king of creation. Evolution reappeared on the lips of priests, journalists and the general public as that which deprived man of his privileged position in the animal kingdom. Claims such as «man is an exceptional creature» ${ }^{62}$ accompanied almost every mention of the theory of evolution. Resistance to accepting this new position was even stronger than resistance to accepting the theory itself. «Theories of evolution, of

\footnotetext{
58. No vivas de espalda a la verdad. Obra de ejercicios parroquiales. La Vanguardia Española. 24 May 1964: 3.

59. Al margen. La Vanguardia Española. 3 Feb 1960: 10.

60. Euras, S. Progresismo. Los ciclos de prosperidad y decadencia. La Vanguardia Española. 2 Dec 1966: 13.

61. To see a complete overview of the linkage of the idea of progress to different evolutionary theories, see Bowler, n. 2, p. 21.

62. Juan, S. El hombre y su origen. La Vanguardia Española. 31 Jul 1965: 11.
} 
natural selection, they are all valid, except in man» ${ }^{63}$ could be read in an article entitled «The man and his origin» in 1965.

The view of evolution held by Crusafont and his group of Spanish palaeontologists escaped all these above associations by placing man in a different category ${ }^{64}$. They allowed for God's intervention and they presented evolution as an ennobling process that led to perfection in humans through the acquisition of the soul, intelligence and spoken language. They moved man away from apes in their discourse, thus giving him back his crown. Man was the "arrowhead of evolution» ${ }^{65}$. There were many examples of this discourse in La Vanguardia Española, as Crusafont wrote articles and books and organised all kinds of events to popularise his view, which were advertised or reported on by the newspaper. The following quotation from a report on a lecture he gave at the Sociedad Astronómica de España $y$ América summarises this:

«Man [...] is the goal of the evolution of species [...] crowned with the acquisition of spoken language. [...] His spiritual part forms a separate world, having a wonderful treasure of spirituality. The primitive man who appeared one million years ago was crude and ape-like, but the soul has ennobled his body to the current Homo sapiens. Our lineage, not linked with known apes, is very old, as 20 million years ago there was a being with humanoid characteristics» ${ }^{66}$.

Crusafont and some other palaeontologists, such as Meléndez, tried to dissociate the concept of evolution from Darwinism ${ }^{67}$. Crusafont wrote in 1951: «For many, evolutionism is still synonymous with Darwinism and to discredit this idea comes [...] this short article» ${ }^{68}$. They were cleaning up evolution's «reputation» by transferring the disturbing links associated with the theory of evolution to Darwinism.

In spite of Crusafont's efforts, some concepts and fears linked to the theory of evolution were also transferred to the sciences that could provide evidence to prove the theory of evolution right. Sciences related to the stu-

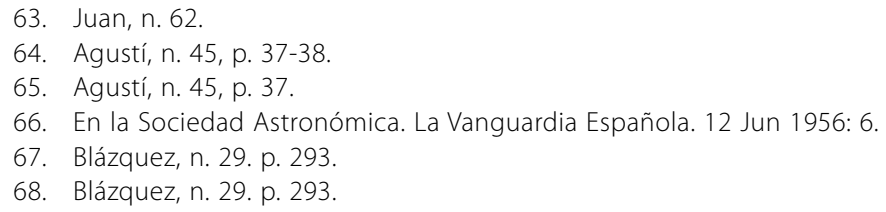


dy of human origins (palaeontology, palaeoanthropology, archaeology and prehistory - used interchangeably in this regard in the paper) were seen as problematic as they provided a materialistic view of the human being ${ }^{69}$. They treated him as an animal and gave people «who read books ${ }^{70}$ a dangerous sense of false progress. The previously described consequent optimism linked to the theory of evolution was also transferred to these disciplines:

«Popular books on archaeology and anthropology deliberately [...] suggest to their readers that the mere passing of time [...] is a proper factor to produce a kind of collective optimism, in which every man must participate today» ${ }^{71}$.

As a result of these «appropriation transfers», these disciplines were regarded as dangerous, as was the knowledge they provided, which had to be transmitted carefully and pass censorship because of the risk of giving «illusions» ${ }^{72}$ to the general public.

\section{Crusafont and the popularity of palaeontology}

Whether it was dangerous or not, palaeontology did manage to find its own way into the public sphere, so successfully that expressions of the sensation that it was becoming more popular can be found in the pages of La Vanguardia Española. According to the newspaper, palaeontology was changing from a dusty, old and boring discipline to something altogether more interesting and fashionable led by a group of young and intrepid scientists. Some of the palaeontological findings at the time contributed to this conception: «The spectacular finding [...] near Madrid has suddenly made palaeontology attractive and popular and has aroused people's curiosity» ${ }^{73}$.

This popularity could perhaps be attributed to the discourse of those Spanish palaeontologists that opened up the doors of the public sphere to evolution. Nevertheless, it is important not to forget the role played by Crusafont with his tireless popularisation activities, his continuous efforts to make both, a national and an international impact, his good relations with

69. Juan, n. 62.

70. Caro, J. Características culturales de nuestra época. La Vanguardia Española. 2 Jun 1966: 57.

71. Caro, n. 70.

72. Caro, n. 70.

73. Investigaciones paleontológicas. La Vanguardia Española. 15 Mar 1959: 21. 
the media, and his large network of fellow scientists ${ }^{74}$ who always emphasised the finalistic-theistic view of evolution. Superlative and high-flown adjectives surrounded his name and highlighted his mastery, intelligence and savoir-faire. National scientific achievements and international recognition were qualities used as propaganda during the Franco regime ${ }^{75}$. Crusafont had the right profile, so Franco's policy benefited his projection in the media and, along with it, the presence of evolution in the public sphere ${ }^{76}$.

Crusafont was also the main populariser in Spain of the works and ideas of Teilhard de Chardin (1881-1955), a well-known French Jesuit palaeontologist ${ }^{77}$, who had a great influence on him $^{78}$. Teilhard defended a concordist, finalistic and orthogenetic view of evolution, understood as an ascendant progress with Man and consciousness at its summit. His ideas, and not only those on evolution, got him into trouble with Catholic authorities on several occasions ${ }^{79}$. Nevertheless, as stated in the newspaper in 1966, at that time it was not possible in Spain to «talk about religion and evolution without mentioning [...] Teilhard de Chardin» ${ }^{80}$. From the late 1960s different positions regarding evolution became visible in La Vanguardia Española. This allowed the appearance of a debate around Teilhard de Chardin that reached boiling point. Priests attacked Teilhard because of his heterodoxy, arguing that he was not a priest, a philosopher or a scientist. His defenders, among them Crusafont, stood up for his contribution to science and concordism. The debate lasted more than a month, from January to March 1968, throughout the course of which the newspaper published more than ten letters to the editor and several articles. The pages of the newspaper corresponding to those dates suggested that there was a real debate in the public arena: «Even housewives talk about him» ${ }^{81}$.

\footnotetext{
74. Acosta, in this dossier.

75. Santesmases, n. 6, p. 733-734.

76. Journalists used sentences such as «with his usual mastery and recognised competence». Merecida condecoración al doctor Crusafont. La Vanguardia Española. 13 Mar 1954: 22.

77. Glick, n. 44, p. 553-555.

78. Catalá, n. 12, p. 12. For a deeper insight into Teilhard de Chardin's influence on Crusafont's thinking, see Agustí, n. 45.

79. Blázquez, F. Entre Darwin y Teilhard. Notas sobre paleontología y evolucionismo en España (1939-1966). Zona arqueológica, 2004; 2(4): 96-101, p. 101.

80. Buetas, Emilio. El evolucionismo biológico. La Vanguardia Española. 22 Oct 1966: 30.

81. Forcadas, Ángel. Teilhard de Chardin. La Vanguardia Española. 15 Feb 1968: 24.
} 


\section{From the monkey grandfather to the hydrogen great-great-grandfather}

Simultaneously, a new discourse was gaining ground in the pages of the newspaper. In 1959, Severo Ochoa (1905-1993), a renowned Spanish biochemist, was awarded a Nobel Prize. This event played a key role in promoting a new generation of young, foreign-trained biochemists and geneticists, with new science policies and media visibility ${ }^{82}$. Moreover, more and more evidence was gathered abroad in favour of the so-called Modern Synthesis, which provided plausible mechanisms for natural selection. ${ }^{83}$ This theory was first expounded in the late 1930s, but did not appear in La Vanguardia Española until the $1960 \mathrm{~s}^{84}$.

In 1963, on the occasion of a lecture given by Ochoa in Madrid on the discovery of the genetic code, La Vanguardia Española published a report entitled «The chemical basis of heredity». It began by explaining the meaning of this achievement to the reader:

«The natures of living species are not immutable. Changes in these natures have led to species being better adapted to survive in the environment in which they live. This is the process of evolution».

Then came the in-depth explanation:

«We have studied it with synthetic nucleotides [...] "poly U" only incorporates phenylalanine into the protein, "poly A" incorporates only lysine, and the combination of "poly UA" and "poly UC" incorporates the same amino acids ${ }^{85}$.

This was a full page article filled with the jargon of biochemistry and genetics. With this more «scientific language», geneticists such as Antonio Prevosti (1919-2011) and biochemists such as Vicente Villar-Palasí (1922-2012) and Joan Oró (1923-2004) began to appear in the pages of the newspaper to document new scientific achievements that were related to evolution. Authority in this field was starting to move from palaeontologists

\footnotetext{
82. Santesmases, n. 6, p. 707.

83. Bowler, 1989, n. 37, p. 314-317.

84. Castro, C. La base química de la herencia. La clave genética. La Vanguardia Española. 3 Jan 1963: 13.

85. Castro, n. 84.
} 
to molecular biologists, from boots to lab coats, from bones to genes, in the pages of La Vanguardia Española ${ }^{86}$.

Antonio Prevosti's maiden speech on his entry into the Real Academia de las Ciencias y las Artes (Royal Academy for Arts and Sciences) in 1969 supported Modern Synthesis ${ }^{87}$ and claimed the authority of genetics in understanding the evolution of species. This discourse was also documented in La Vanguardia Española:

«Particularly the huge advances made in the understanding of the genetic constitution of hereditary material, especially nucleic acids, allowed the interpretation of the mechanism of evolution» ${ }^{88}$.

This new way of approaching evolutionary theory in the newspaper concerned the adoption of a more esoteric language that included technical words from genetics and biochemistry. In an account of a new scientific achievement in which the paper asked some scientists and a theologian about the implications of this discovery for the theory of evolution, an indepth article by Villar-Palasí explained:

«This achievement means in all probability the exact duplication in the laboratory by the action of cellular «replicase-type» enzymes, of the deoxyribonucleic acid molecules (DNA), which are the fundamental and most precious possession of animal viruses, as well as of the chromosomes carrying the genetic heritage of all cells» ${ }^{89}$.

The use of this vocabulary could be one of the factors that mitigated the discussion of origins related to evolution in terms of philosophical and theological debate in the public sphere. It left aside the decimononical popular imaginary of the scale of progress (with the erecting stages from apes to humans), moving the focus of attention from men who resembled

86. A profound analisis of the genetisation of vocabulary and concepts in the case of palaeoanthropology can be found in Sommer, Marianne. History in the gene: negotiations between molecular and organismal anthropology. Journal of the History of Biology. 2008; 61: 473528. See also Smocovitis, V. B. Humanizing evolution. Current Anthropology. 2012; 53 (S5): S108-S125 (S111).

87. Blázquez, n. 15, p. 66.

88. El doctor Prevosti Pelegrín, miembro de la Real Academia de Ciencias y Artes. La Vanguardia Española. 17 Jun 1969: 32.

89. Villar-Palasí, Vicente. Otro paso para revelar los orígenes de la existencia. Significación de un gran hecho científico. La Vanguardia Española. 16 Dec 1967: 17. 
apes to changes in nucleotides and molecular interactions and understanding evolution as «a process of information gathering» ${ }^{90}$. This new conception did not evoke the idea of effortless improvement. That jargon could be experienced as more «aseptic», far removed from belief and that had little to do with people's roots and family trees. Moreover, it could also be seen as too far removed from the religious and political discourse to threaten the Catholic faith or political doctrines. The theory of evolution in these new terms became less impacting on the beliefs and values of the public. In addition, by moving the initial focus point of evolution from the monkey to the origin of life, the rejection of the theory due to the displacement of Man from his position as king of Creation lessened. Joan Oró himself stressed this point by defining the motto «From Hydrogen to man» which the paper labelled, «The Theory of Doctor Oró». Moreover, «his theory» did not discredit the idea of God as the Creator:

«Some people [...] think that life began as a single act. This is false. Life is the result of a series of evolutionary processes. [...] What I cannot say, as a scientist, is where the origin of the origin is. That is, how hydrogen was created $»{ }^{91}$.

The new discourse with its new authorities began gathering momentum in the pages of La Vanguardia Española until it became hegemonic. From the late 1960s the associations that had forced a rejection of evolution slowly started to become less relevant and the theory of evolution gradually began to appear in the pages of the newspaper, mainly in the 70s, when such sentences as: «evolution is a fact that has been universally accepted ${ }^{92}$ are increasingly found.

\section{Conclusions}

The way evolutionary theory was dealt with in La Vanguardia Española went through an evolution in itself parallel to the gaining and subsequent loss of palaeontological authority over evolution in the newspaper. It is possible to trace its presence in some of the political and social changes

\footnotetext{
90. El doctor Prevosti Pelegrín, n. 88.

91. Interesantes comunicaciones sobre el origen de la vida en el VI Congreso de Bioquímica. La Vanguardia Española. 10 Apr 1969: 11.

92. Sarro, Arturo. Viaje a las islas Galápagos. La Vanguardia Española. 20 Jan 1974: 47.
} 
that took place during the Franco dictatorship. First came an «evolutionary silence» from the end of the Civil War in 1939 to the 1950s, during the first strictly autarchic period. Next, a rigid pattern for articles that mentioned evolutionism can be found. On the one hand, there were those linking it to pejorative concepts and fears and rejecting it due to its threat to the Catholic faith. On the other hand, there were those related to palaeontology, which stressed a view opposite to all the aforementioned unsavoury links and stated that evolution was agreeable and not at odds with dogma. Most articles required «a religious bodyguard» and palaeontology was the official scientific authority on evolution. This pattern was hegemonic until the mid-1960s, when the regime started to become more open. Following the new Press Act in the late 1960s, a debate around Teilhard de Chardin emerged in the pages of the newspaper that revealed different opinions on evolutionism. Besides this, in the mid-1960s, a new discourse on evolution by biochemists and geneticists was breaking through in the pages of the newspaper using new, modern scientific jargon. It started gaining ground for authority to speak on evolution to the detriment of the palaeontologists. The new discourse fitted in well with the new policy of the regime, which sought to shift from tradition to modernity. Finally, during the 1970s, with the decadence of the regime, the theory extricated itself from religion and its presence increased in the pages of La Vanguardia Española. This ongoing appropriation goes hand-in-hand with the theory's link to certain concepts or ideologies, its use for different purposes and its fate depending on the political environment.

After the Civil War in 1939, Spanish educational manuals and catechisms changed the evolutionary approach to human origin to a theological one and Darwin's works disappeared from Spanish libraries and bookshops. This paper demonstrates how this suppression also affected the press, as evidenced by the silence in La Vanguardia Española until the 1950s. Persecution of Republican vestiges and the strict Catholicism of the Franco regime labelled the theory of evolution as proscribed ${ }^{93}$. In 1950, Pope Pius XII issued he Humani generis encyclical, which allowed Catholic learned men to debate evolution. Some Spanish palaeoanthropologists led by Miquel Crusafont took advantage of this. They offered a finalistic-theistic version of evolution, which was compatible with Catholic dogma and which fitted

93. Blázquez, n. 15, p. 56. 
in well with the current demands of the regime. In this way, palaeontology managed to break the evolutionary silence in La Vanguardia Española and become the official scientific voice of evolution. This paper highlights the hegemonic presence of this view in the newspaper, as the authority allowed to transmit this knowledge. The adhesion to this «regime-style» evolution could be interpreted as a conscious strategy by Crusafont and his group of Spanish palaeontologists to gain authority or public visibility. There is some evidence that points to this ${ }^{94}$. However, this may not be the case, as most French palaeontologists of the time also supported the finalistictheistic view of evolution in a completely different context ${ }^{95}$. There is also evidence of Crusafont's internal struggle in this regard ${ }^{96}$ and his will and effort to match these views with scientific evidence seem too strong to be mere strategy.

Moreover, Crusafont's huge popularisation efforts have to be taken into account with regard to the presence of palaeontology in the newspaper. Numerous accounts mentioning evolution were reports or advertisements of events organised by him, stressing this finalistic-theistic view of evolution. Crusafont appeared in the pages of La Vanguardia Española far more often than the rest of the palaeontologists of his time. Despite the fact that Crusafont felt isolated and saw himself as peripheral to both the Spanish and foreign scientific communities ${ }^{97}$, the press presented him as a national hero, an important part of Spanish scientific society, who was well connected and highly regarded by the foreign scientific communities. Through him, the regime exalted national ability by using science in the press as propaganda ${ }^{98}$.

Besides the ongoing appropriation of the theory of evolution, which continued to link it to unfavourable concepts until the mid-1960s, this paper highlights how these appropriations were transferred to closely related disciplines. As it was able to provide evidence to prove the theory, palaeontology was associated with the same conceptual links as evolutionism. Thus, it somehow suffered the same fate, as it was seen to be dangerous,

94. See Crusafont's letter to Simpson on 29 Oct 1961 in Glick, n. 44, p. 562-563. See also Acosta, in this dossier.

95. Blázquez, n. 29, p. 298, 307.

96. Agustí, n. 45, p. 42-43. See also Glick, T. Miquel Crusafont i George Gaylord Simpson. Interferències biogràfiques, confluències històriques. Arraona. 1994; 3 (14): 164-165.

97. Acosta, in this dossier.

98. For a similar case see Santesmases, n. 6. 
sometimes being rejected due to this association. The newspaper provides evidence of the struggle waged by palaeontology against these links. In contrast, the newer Modern Synthesis, also closely related to the theory of evolution, seemed to leave behind its ideological charge and extricate itself from religion. Genetics and synthetic theory provided evolution with a «more scientific» language, which subsequently gave it an aura of modernity that was well suited to the new phase of openness in the dictatorship.

As Thomas Glick, who made an in-depth study of the reception of Darwinism in 19th-century Spain, claimed:

«The key to understanding the social history of scientific ideas must be found, firstly, at the level of communication networks that comprise the immediate arena in which ideas are received and, secondly, in the interaction between the academic and popular reception of these ideas. If we address these problems, we will get a clearer picture of the role of science in modern Spain ${ }^{99}$.

Besides reconstructing part of the public sphere regarding the case of evolutionary theory, this paper aims to contribute to the understanding of the social history of the sciences related to evolution. By studying their roles in the reception and appropriation of scientific knowledge in the public sphere, this case highlights the «struggles and strategies» to gain authority in a broader context, beyond scientific circles, as well as how this broader context shapes the knowledge that those sciences are supposed to generate.

\section{Acknowledgements}

I want to thank my two referees for their enriching comments and criticisms and also Miquel Carandell, Oliver Hochadel, Pedro Ruiz-Castell, Jesús Català Gorges and Jaume Sastre for their helpful readings of preliminary drafts. 